\title{
MGST2 Gene
}

National Cancer Institute

\section{Source}

National Cancer Institute. MGST2 Gene. NCI Thesaurus. Code C107110.

This gene plays a role in the metabolism of leukotriene C4. 